\title{
THE IMPORTANCE OF ELECTRONIC EDUCATION METHODOLOGY
}

\author{
Fotima Anarbaeva
}

Lecturer, Samarkand Branch Of Tashkent State University Of Economics, Uzbekistan

\section{ABSTRACT}

E-learning is based on the use of multimedia and Internet technologies to improve the quality and opportunities of education using an innovative approach to education. With this in mind, this article discusses the specifics of e-learning and traditional education, the research of foreign scholars on e-learning methods, the importance of e-learning methods and Sergeev S.F., Nabi Y.A., Ibraimov A.E. such as the research of scientists in the field of e-learning methodology.

KEYWORDS:- Traditional education, e-learning, educational content, e-learning didactics, methodology, elearning methodology, e-textbooks, e-learning development methods, teaching quality, multimedia technology, internet technology, innovative approach, pedagogical aspects, educational process, student, teacher.

\section{INTRODUCTION}

In the current era of globalization and digitalization, it is important for e-learning to enter the educational process. Traditional and elearning aspects are intertwined in terms of certain features. E-learning serves to improve the quality and opportunities of education through the use of innovative approaches to education, including multimedia and Internet technologies. With this in mind, e-learning can be considered as an opportunity for students to acquire knowledge in a comfortable organized environment. The development of e-learning methods requires the creation of distance learning courses in e-learning with a systematic approach in accordance with the curriculum, the acquisition of modern knowledge and insights using innovative educational technologies.

The degree of study of the work
Modern technologies have entered traditional education with the renewal and preservation of some aspects, and as a result, the concept of elearning has emerged in the field of education.. Elearning allows students to use once-created multimedia educational content multiple times in an interactive mode. In this way, students will not only be able to observe the process of creating content, but also create it. E-learning forms social networks, forums, chats in educational content. In addition, they allow the development of a dynamic model of site content improvement.

In the traditional education system, textbooks are updated every three to four years, but in elearning, e-textbooks are updated daily and allow you to switch to another resource through hyperlinks in an optional e-learning resource, while retaining the features of traditional education. 
CURRENT RESEARCH JOURNAL OF PEDAGOGICS 2(6): 127-130, June

2021 DOI: https://doi.org/10.37547/pedagogics-crjp-02-06-24

ISSN 2767-3278

(C)2021 Master Journals

\section{Crossref do) 81 Google}

Accepted 25thJune, 2021 \& Published 30 th June, 2021

In e-learning, the teacher must master the methods of distance communication. This also allows the teacher to create, complete, edit, and publish teaching materials. As a result, the form of organization of lectures will change. In traditional education, the student is given previously unknown information, and in elearning, all learning materials are presented to students in an orderly manner in the form of various formats of information transfer. Therefore, the teacher will now be able to take a creative approach to the lecture, provide students with sources of information to prepare for, or the students themselves will be able to find additional sources of information. Then the report will be discussed. During the discussion, students' opinions on the report are considered and a general conclusion is reached. The teacher also provides students with independent work topics [4] (Анарбаева Ф.У. ва б., 2020).

E-learning is based on the use of multimedia and Internet technologies to improve the quality and opportunities of education using an innovative approach to education. Many foreign open and virtual universities operate on the principle of elearning, which competes with traditional forms of education. E-learning changes the form and environment of education according to the wishes of the student and the teacher. E-learning allows students to learn in a comfortable organized environment.

In general, the methodology is a set of recommendations for the organization and conduct of the educational process. From this, we can define the methodology of e-learning - the development of its organizational, structural structure, including all aspects of e-learning, as well as the organization of pedagogical management of e-learning. A lot of research work is currently being done on e-learning methodology, in particular Buus L., Georgsen M., Olitayo P., Sergeev S.F., Nabi Y.A., Ibraimov A.E. such scientists have done a lot of research in this area.

In his work, SF Sergeev sees e-learning methods as e-didactics. In his opinion, "to create an effective e-learning, it is enough to model the field of work, tasks and goals of the teacher using technology, and this is the basis of a complex science - e-didactics of teaching methods in the new pedagogical reality of the technical age.". This leads to the following opinion about the pedagogue working in e-learning: "The transition to computerized education today is associated with the peculiarities of public education in the information world.The level of emergence of relevant knowledge exceeds the capacity of education systems to master them. There are problems in training and retraining of qualified pedagogical staff among graduates of higher education institutions. The first logical solution is computer-based education. Thus, S.F.Sergeev said that after graduating from higher education, teachers should first of all develop as specialists in their field, and in the field of e-learning they do not have enough knowledge, so it is necessary to organize training and retraining in e-learning. passes. [3] (Сергеев С.Ф., 2015).

Regarding didactics, A.E.Ibraimov described it as follows: "Didactics serves as a basis for teaching methods of each subject, as well as defining the general laws and regulations of teaching. Didactics serves as a methodological basis for the whole pedagogical activity, ie for the theoretical and practical actions of those involved in education.". It follows that didactics plays an important role in the development of e-learning methods [1] (Ибраймов, 2020).

Methods of e-learning development are also considered in the involvement of e-learning in the educational process, which Nabi Y.A. as shown in his work: "Systematic approach. The systematic approach is determined by the application of the tools of the general theory of the system. In general, a systematic approach 
CURRENT RESEARCH JOURNAL OF PEDAGOGICS 2(6): 127-130, June

2021 DOI: https://doi.org/10.37547/pedagogics-crjp-02-06-24

ISSN 2767-3278

(C)2021 Master Journals

\section{Crossref do) 81 Google}

Accepted 25th June, 2021 \& Published 30 ${ }^{\text {th }}$ June, 2021

forms the basis of the methodology. This method can also be considered as a method of forming innovation systems. Dialectical approach. The dynamic nature of the processes taking place in the educational process is the result of the constant desire of the subjects of the educational process to improve, to move from the old to the new.. Expert assessment methods. The research methodology should be based not only on theoretical foundations, but also on empirical verification of the results obtained. Various methods of reliability testing: observation, pedagogical experiment, questionnaires and interviews, expert evaluation, etc. are widely and widely used in pedagogy. Given the theoretical features of e-learning, it seems impossible to use observation, pedagogical experiment and other methods. The expert evaluation method is based on a questionnaire and an interview" [2] (Nabi, Yskak A. et al., 2017).

As a result of the above scientific research, the methodology of e-learning can be considered in the following aspects.

1. General issues of e-learning. It addresses the issues that form the basis of e-learning. These include the following issues: pedagogical issues, technological issues, pedagogical design, the purpose of pedagogical design, features of pedagogical design.

2. A process approach to e-learning. It considers the process of creating e-learning and its pedagogical basis. These include: process model, pedagogical design of process approach.

3. Teacher training. The activity and professional training of teachers play an important role in the organization of e-learning.

4. Forms of organization of e-learning. The following forms of organization of e-learning can be distinguished: lectures, practical training, organization of independent learning.

5. Active methods of e-learning. It considers active ways of organizing e-learning. These include: general systematic approach to pedagogical activity, active methods of elearning, guidelines for webinars.

6. Use of multimedia in e-learning. At the same time, the areas of application of multimedia are considered as important aspects of the organization of e-learning.

In general, the methodology of e-learning is the creation of distance courses of e-learning in accordance with educational programs with a systematic approach, having modern knowledge and views using innovative educational technologies, ensuring consistent, systematic, continuity of theoretical and practical knowledge studied by students, ensuring regular control and evaluation of students ' knowledge and assimilation on the basis of observation-controlassessment, it is desirable to regularly check the knowledge and skills of the teacher of the course, as a result of questionnaires and assessments of his pedagogical activity.

\section{Conclusion}

On the basis of the above, we can say that the methodology of e-learning has entered the educational process on the basis of the issues that form the basis of e-learning, its pedagogical bases, the activities and professional training of teachers in the organization of e-learning, the forms of Organization of e-learning and the application of multimedia technologies in. Elearning is widely used by higher education institutions in the conditions of current paedemia, the development of this sphere continues at a rapid pace.

\section{REFERENCES}

1. Ибраймов А.Е.. Масофавий ўқитишнинг дидактик тизими. - Тошкент: "Lesson 
CURRENT RESEARCH JOURNAL OF PEDAGOGICS 2(6): 127-130, June

2021 DOI: https://doi.org/10.37547/pedagogics-crjp-02-06-24

ISSN 2767-3278

(C)2021 Master Journals

Crossref dof 81 Google

Accepted 25th June, 2021 \& Published 30 ${ }^{\text {th }}$ June, 2021

press", 2020, 112 бет.

2. Nabi, Yskak A. et al. "Methodological aspects of E-Learning innovativeness Aspectos metodológicos de la innovación del E-Learning." (2017).

3. Сергеев С.Ф. Методологические проблемы e-learning дидактики // Открытое образование. 2015. №3. URL: https://cyberleninka.ru/article/n/metodo logicheskie-problemy-e-learning-didaktiki

4. Taylakov, Norbek Isakulovich, and Fotima Urazalievna Anarbaeva. "Pedagogical Features of Moodle Platform." The American Journal of Applied sciences 2.07 (2020): 104-107.

5. Anarbaeva, Fotima Urazalievna, Asqar Abduhakimovich Abdullaev, and Abduvafo Fazliddinovich Qoraev. "Pedagogical approach to the use of electronic education in the educational process."

6. Anarbaeva F. METHODOLOGICAL PROPERTIES OF THE MOODLE PLATFORM IN THE ORGANIZATION OF E-LEARNING //IEJRD-International Multidisciplinary Journal. - 2020. - T. 5. - №. 4. - C. 7.

7. Shavkatovich M. M. Issues in Accounting Systems Design to Report Innovation in Organizations //International Journal of Progressive Sciences and Technologies. 2021. - T. 24. - №. 2. - C. 68-72.

8. Shomirzayev, M. K. (2020). EDUCATION IS PERSONALLY FOCUSED TECHNOLOGY. European Journal of Research and Reflection in Educational Sciences Vol, 8(8).

9. Shomirzayev, M. K. (2020). The concept of pedagogical technology and basic principles. ACADEMICIA: An International Multidisciplinary Research Journal, 10(11), 1551-1560.
10. Farfieva K. A. Social Media as a factor in formation of scientific thinking in youth. European Journal of Research and Reflection in Educational Sciences. Vol. 8 No. 10, 2020. - Pp. 52-56. 